\title{
Freedom Without Responsibility: the Promise of Bolsonaro's COVID-19 Denial
}

\author{
Thomas Bustamante $^{1}$ (D) $\cdot$ Conrado Hübner Mendes ${ }^{2}$ (D)
}

Accepted: 23 August 2021/Published online: 31 August 2021

(c) The Author(s), under exclusive licence to Springer Nature Switzerland AG 2021

\begin{abstract}
Jair Bolsonaro, the current President of Brazil, has made himself into one of the most influent advocates of COVID-19 denial. His health policy and his political doctrine are partly based on an implicit moral claim, which is neglected by contemporary political theory. Bolsonarism's rhetoric raises a moral claim to freedom without responsibility, which relieves its followers from the burdens that emerge from liberal accounts of liberty or from basic goods accepted in a political community. In opposition to liberal or communitarian accounts, Bolsonarism endorses a Hobbesian concept of freedom that describes it as the absence of 'impediments to motion'. Nonetheless, it differs from Hobbes because it treats this liberty as endowed with moral value and non-negotiable through a social contract.
\end{abstract}

Keywords Bolsonaro $\cdot$ COVID-19 $\cdot$ Denialism $\cdot$ Liberty $\cdot$ Kant · Communitarianism $\cdot$ Hobbes

\section{Introduction}

Jair Bolsonaro, the current President of Brazil, has made himself into one of the most influent advocates of COVID-19 denial. His political practice resorts to more than an ordinary form of populist rhetoric: he repeatedly denies the seriousness of the disease and is committed to let millions of people be infected with the coronavirus. He promises his followers that through exposure to the virus, the country can protect the economy and achieve a herd immunity, regardless of the recommendation

Thomas Bustamante

tbustamante@ufmg.br

Conrado Hübner Mendes

chm@usp.br

1 Faculty of Law, Federal University of Minas Gerais, Belo Horizonte, Brazil

2 Faculty of Law, University of São Paulo, São Paulo, Brazil 
of the scientific community to adopt social distancing measures until vaccines are made available in a large or universal scale. ${ }^{1}$

Bolsonaro and his supporters consistently ignore the warnings of science. Not only do they advertise ineffective and dangerous drugs, but they also campaign against the use of masks, raise doubts against vaccines, and sabotage social distancing measures adopted by local authorities and other political institutions like the legislative branch or the Federal Supreme Court. His supporters claim that any government's intervention in the circulation of people or in social, educational, or economic activity is illegitimate and should be repealed.

Although most academic observers dismiss Bolsonaro's political project as morally obnoxious, one of its most intriguing aspects is that it offers its supporters a radical, though fragmented, incoherent, and not expressly articulated, moral justification. Since the beginning of his long political career, Bolsonaro voiced a conception of freedom, which we will attempt to unpack in this article.

The absence of analysis of this conception of freedom produces a serious political handicap. It renders participants in public debates incapable to effectively respond to the supporters of Bolsonarism. In the eyes of a Bolsonarist, philosophers of liberal, communitarian, or even Hobbesian persuasion present only question-begging arguments against her interpretation of the value of freedom. They fail to convince because they are unable to understand the Bolsonarist's moral and political world.

It is urgent to reconstruct the premises of Bolsonaro's denialist attitudes toward COVID-19. The aim of this article is to debunk the implicit commitments of Bolsonarism and articulate them as an explicit set of ideas, to show their inconsistency and implausibility. We aim, in other words, to offer an account of the concept of liberty that underlies the ethical claims of Bolsonarism, which may help one see how this value was able to persuade supporters despite the irrationality of its responses to the threat of COVID-19.

The recent literature on Brazilian illiberalism has made some progress to analyse one of the aspects of Bolsonarism's ethical assumptions, which is the concept of 'good citizen'. ${ }^{2}$ Nonetheless, another important part of this political agenda remains underexplored: the notion of freedom that lays implicit in Bolsonarism. Although this conception has been endorsed by Bolsonaro since his earliest public pronouncements, the Brazilian government's responses to COVID-19 make this doctrine more salient and its practical consequences easier to assess.

We will take the following steps to explain this view. In Sect. 2, we describe the concept of 'good' citizen, which constitutes a central aspect of Bolsonaro's ethical doctrine. In Sect. 3, we describe Bolsonaro's account of freedom, which is a less known but equally important part of Bolsonarism. In Sect. 4, we turn to the concrete implications of this account of the good citizen's responses to COVID19. In Sects. 5, 6 and 7, we compare this view of freedom with the conceptions presented by Kant, the communitarian tradition, and Thomas Hobbes. In Sect. 8,

\footnotetext{
1 Ventura 2021.

2 Santos 2012, 137; Solano 2018, 12-14; Kalil 2018, 14.
} 
finally, we unpack the features of the Bolsonarist freedom that make it attractive to its supporters.

\section{The Good Citizen and the Ethics of Bolsonarism}

According to Rawls's theory of 'justice as fairness', a well-ordered society either is or inevitably becomes morally pluralistic. ${ }^{3}$ This assumption neither requires that a well-ordered society only can be built in a pluralist environment, nor sustains that a nonpluralist society, by some sort of natural necessity, will automatically become pluralist once its citizens commit to liberal principles. The gist of Rawls's claim is, instead, that liberal societies provide opportunities for multiple ethical choices, including some incommensurable yet reasonable choices.

It is this entailment that allows for different comprehensive doctrines to coexist and over time tends to accommodate multiple worldviews. For as long as none of these comprehensive doctrines of the good undermines the principles of justice, each of them can be supported by the equal liberty that all members of a wellordered society enjoy. Given the multiplicity of valuable projects in which a person can engage, the idea of a well-ordered society must be built on an overlapping consensus achieved by citizens who may have different and opposing comprehensive doctrines of the good. Democratic societies are characterized, therefore, by an enduring commitment to common principles of justice regardless of the pluralism of 'reasonable though opposing religious, philosophical and moral doctrines'. While all comprehensive doctrines must affirm a political conception of justice, the possibility of a reasonable pluralism is a 'permanent condition of a democratic society'.

As a rule, part of the plan of illiberal regimes is to undermine the ethical pluralism that either exists or inevitably comes about in a liberal society. The mark of an anti-liberal polity is that it is aimed at a 'continuing shared adherence to one comprehensive doctrine'. ${ }^{5}$ On Rawls's interpretation, this endorsement of a unique comprehensive doctrine is possible only through the extensive use of coercive powers by the political institutions of a given state. Nevertheless, one of the central features of Brazilian anti-liberalism is that it does not purport to unite its supporters under a single doctrine of the good.

Bolsonarism is not a comprehensive political doctrine, since it lacks either a 'coherent scheme of ideas' or an integrative political worldview. ${ }^{6}$ Part of what unites its supporters is an antiestablishment doctrine resentful to political parties, intellectuals, and traditional elites. Like the most usual forms of populist ideology, it attempts to distinguish between a 'virtuous' and 'homogeneous people' and a poorly defined set of 'others', who are jointly portrayed as a threat to the 'rights, values,

\footnotetext{
${ }^{3}$ Rawls 2001, 33.

4 Ibid., 33.

5 Ibid., 34.

6 Salles 2020.
} 
prosperity, identity and voice' of the genuine people. ${ }^{7}$ Given its populist element, Bolsonarism presents itself as 'a thin-centered ideology that considers society to be ultimately separated into two homogeneous and antagonistic camps, "the pure people" versus "the corrupt elite", and which argues that politics should be an expression of the volonté générale (general will) of the people'. ${ }^{8}$

Nonetheless, Bolsonarism is unclear about the goods that one should pursue. 'Bolsonaro invests in acts of destruction, instead of visions about the future' ${ }^{9}$ When it comes to his positive proposals, his thoughts are contingently borrowed from other doctrines (economic neoliberalism, law and order accounts of criminal law, militarism, religious doctrines against 'gender' complaints, libertarian arguments against taxation, conservative arguments against egalitarian claims for the LGBT + community, resentment against social benefits, affirmative action or laws for labour protection, and so on), with no attempt to integrate these views in an intelligible program.

A nuclear element of Bolsonarism is the claim that a political leader should govern only for the 'good citizens', who share the virtues of the political leader instead of the vices of his opponents. The concept of good citizen, which is sometimes described as a 'model' citizen, ${ }^{10}$ plays a crucial role in this ideology because it delimitates a narrower boundary for the concept of citizenship. Neither being born in a community nor having a legal relationship with the state is considered enough to achieve this particular status. You must commit, instead, to the mindset that is embodied in Bolsonaro's moral and political practice. The concept of good citizen fixes the scope of legitimate policies and the rightful beneficiaries of state protection. It presents itself as an alternative to the universalistic claim of human rights, the core element of which is the belief that dignity is not a predicate that everyone can have. For the good citizen, dignity is a status earned by those who mimic the president and lack the vices that can destabilize that particular form of life.

It is important, in this populist doctrine, that the status of a good citizen is achievable to the ordinary man. The only special virtue that it requires is an unconditional fidelity to the leader and the social order that he defends. Good citizenship requires a special relationship with the populist leader, rather than any intellectual, moral, or civic capacity. Bolsonarism can be classified as an 'illiberal' version of populism, in the sense that it presents itself as sceptical of public reason and enlightenment values. ${ }^{11}$

As it has been demonstrated in a study on the visual self-presentation of Bolsonaro, he displays himself as an ordinary man, 'a mirror of the people'. ${ }^{12}$ Bolsonaro's transgressive behaviour has the symbolic effect of desecrating the presidency. His populist aesthetics creates an identification with the subjects, for his body "carries

\footnotetext{
7 Albertazzi and McDonnel, 1.

8 Ibid., 6. See also Müller 2016, 171.

9 Salles 2020.

10 Mafei, Bustamante and Meyer 2021.

11 For a more refined development of this opposition between illiberalism and enlightenment, see Garrard 2021.

12 Mendonça and Caetano 2020.
} 
with it the presence of his followers in a transgressive manner'. ${ }^{13}$ Bolsonaro manages, thus, to persuade his supporters that it is an extraordinary fact that a common man like him has reached the highest office of a powerful country. He extends to his followers an invitation to share this achievement and offers an opportunity to replicate it in their own private affairs and in their public endeavours in politics. He offers his followers a right to the same transgressive behaviour he adopts.

When Bolsonaro sits in the highest office and licenses police violence against malefactors, pardons his followers' hostility against gay persons, communists, and indigenous populations, or grants to the good citizen the right to carry guns, physically punish her children, and dismiss as antithetical to Christian values any claim to gender equality, he offers to the good citizen a justification for her prejudices and unexamined views. He offers, in other words, an excuse to place her interests in front of the interests of others in the community, a genuine exemption from responsibility.

There are two features that we must unpack to understand this ethos.

First, the good citizen need not be a rational agent. Her canine fidelity prevents her from making inferences and critical judgments about her conduct. The model citizen is presented with a pedigree test for her beliefs. Each belief stands or falls alone, with no need to synthesize them in a rational network. One assesses the validity of a belief in an atomistic way, since the only exigency to validate it is the approval of the populist leader. The model citizen is entitled to her interests for as long as these interests are not disqualified by the government and classified as a vice she cannot have. Authority, rather than reason, determines the soundness of a moral belief. Although a rational agent would perceive this as a loss of freedom, in the sense that we will specify in the upcoming sections of this article, the model citizen receives this message both as a consolation and as a prize, for she is discharged from the burden to assess herself. She is entitled to act in an arbitrary way. She no longer needs to justify her choices because the populist leader, whose ascension to the highest office is portrayed as an extraordinary achievement of the ordinary people, is there to bless whatever the model citizen decides. Since the populist leader is also a model citizen, she will approve whatever the genuine model citizen thinks or does.

Second, the model citizen receives a license to care only about herself. She is granted a right to her own idiosyncratic practical code. The upshot of this license is an extremely individualistic morality, according to which one's interests and convictions need not be balanced against competing interests of the community. The relation between rights and obligations becomes asymmetrical, for the asymmetry between 'model' citizens and 'ordinary' citizens turns the latter into 'pseudo-citizens' whose rights or interests can be cast aside. On the model citizen's conceptual scheme, this distinction eliminates the exigency of reciprocity among entitlements and obligations. The model citizen, therefore, no longer has to distinguish between her urges and rational desires, ${ }^{14}$ and no longer needs to measure the plausibility of her beliefs against a set of binding rational norms. She becomes entitled to an

\footnotetext{
13 Casullo 2018, 1.

14 See, on this distinction, Raz (1999, 54), who holds that only the former (urges) must be curbed, because they are not part of the set of options we retain in order to track our legitimate reasons for action.
} 
arbitrary attitude in the political arena, failing the rule of law by showing indifference to the 'proper reasons' for which coercion or any kind of social power can be legitimately employed. ${ }^{15}$

Once one perceives oneself as a good citizen, and once the populist leader reinforces this perception by treating her in this way, one is endowed with a freedom to pursue one's interests without acknowledging the claims of the persons who lack this superior moral status. The leader and the model citizen become united because the former shares with the latter his simplicity, ignorance, transgressive behaviour, aesthetics, values, and prejudices. In a sense, the model citizen needs the pseudocitizen or the 'enemy of the state' because she needs the distinction between her special status and the status of the leader's adversaries. Through the acknowledgment of the 'others' who lack her honorary status and special rank, the model citizen becomes invested not merely with a special form of respect, but also with the right to fight for this status. One can legitimately protect this status resorting to violence, hatred, racial prejudice, misogyny, political persecutions, because the model citizen's moral code does not acknowledge any reciprocity for her rights.

\section{Liberty According to Bolsonarism}

President Jair Bolsonaro has been elected with a fierce and resentful hate speech against identified minorities and specific social and political groups. Part of his message in the electoral campaign was a commitment that his presidency would reestablish the legacy of the 1964 military dictatorship, including this government's practices that led to convictions of the Brazilian republic in the Interamerican Court of Human Rights. ${ }^{16}$ In the last Sunday before the election, for instance, he broadcasted a pronouncement to millions of persons, thousands of them assembled in São Paulo's largest and busiest boulevard, with a promise to send his political opponents to the 'edge of the beach'. 17

One must resort to the context of the military dictatorship to understand what he meant by this. The 'edge of the beach' was a short name for a military base called 'Restinga da Marambaia', in the state of Rio de Janeiro, which was used during the military dictatorship for unregistered disposal of human bodies of victims who died under torture in the hands of the military regime. In his long career as a member of the House of Representatives, Bolsonaro defended and paid tribute to paramilitary groups (known as milicias) that took control of certain areas of the state of the Rio de Janeiro, promising to install a dictatorship once he takes office as president of Brazil. ${ }^{18}$ On several occasions, including after he became president and social

\footnotetext{
15 Raz 2019, 5.

16 Gomes-Lund et al. (Guerrilha do Araguaia) v. Brazil, Inter-American Court of Human Rights (IACrtHR), 24 November 2010; Herzog et al. v. Brazil, Inter-American Court of Human Rights (IACrtHR), 15 March 2018.

17 For a short notice in English, see The Guardian (2018).

18 Franco 2018. See also Meyer 2021, 141-148.
} 
distancing measures were imposed by other spheres of government to implement social distancing and prevent the spread of COVID-19, President Jair Bolsonaro participated in anti-democracy rallies and demonstrations to intimidate the two Houses of Congress and the highest body of the judicial branch (the Federal Supreme Court).

Part of the rhetorical package of Bolsonarism is a permanent threat to re-install the most severe authoritarian act in the Brazilian history, the Institutional Act 5 of 1968, also knowns as AI-5, which authorized the federal government, among other things, to put the legislative branch under indefinite recess, suspend all the constitutional instruments to protect human rights, make arbitrary detentions, remove from office any public official, and intervene in the judicial branch. ${ }^{19}$

This populist rhetoric suggests a conflict between democracy and freedom, and purports to attack the constitutional order indirectly, 'eroding' rather than abrogating it. ${ }^{20}$ Under Bolsonaro's presidency, a counterintuitive conception of freedom gained traction in Brazil, which can be called freedom without responsibility. This putative conception of liberty claims to vindicate a right to unrestricted freedom and to describe the content of liberty as a domain of unbridled discretion and irrational whim.

To understand the Bolsonarist account of 'freedom', one most turn to its impact on very concrete daily matters, like our personal actions as a parent, a husband or wife, or even as a driver in a public road. Bolsonaro's views on traffic regulations are particularly instructive. He argues for a liberty to drive with less regulation (for instance without submitting professional drivers to a periodic toxicological examine and dispensing parents from carrying children in safety seats), fewer speed cameras, and less strict penalties for traffic offenses (doubling the number of points that a driver can lose in Brazil's point-system penalties to lose her driving license). ${ }^{21}$

In a similar way, when it comes to the rights of children and adolescents, Bolsonarists uphold a view on 'economic freedom' that militates against labour laws that forbids child labour and other forms of degradant treatment to infants and adolescents, ${ }^{22}$ and a view of family relationships that campaigns for the parents' alleged 'freedom' to beat their children. ${ }^{23}$

This conception of freedom is also sceptical of any environment protection laws and advocates a 'right' to trespass indigenous reserves to mine for gold, or to illegally $\log$ in environmental protection areas. ${ }^{24}$ It includes, further, a freedom (of farmers) to use pesticides prohibited almost everywhere in the world, with weak regulations on the deployment of these substances and no duty to inform consumers of their risks. ${ }^{25}$

\footnotetext{
19 Meyer and Bustamante 2020 and 2021.

20 Meyer 2021, 7-10.

21 Andrés 2019.

22 Fernandes 2019.

23 Martins 2020.

24 Ferrante and Fearnside 2019.

25 Phillips 2019.
} 
These commitments can be classified as a severe restriction on personal freedom. Bolsonarism's crusade in defence of its prejudices has denied thousands of individuals their most fundamental liberal rights. Its endeavours and moralizing battles are based in the thought that model citizens have a legitimate claim to impose obstacles, restrictions and constraints in the liberty of the pseudo-citizens that they define as adversaries of the regime. When we consider the actual impact of this belligerent rhetoric, we discover an alarming increase of violence, including mortal violence, inflicted against indigenous populations, ${ }^{26} \mathrm{LGBT}+$ persons,${ }^{27}$ and racial minorities, in particular against black people. ${ }^{28}$ The statistically significant increase of violence against these populations is causally related to the exponential increase of Bolsonaro's ideology of hate. ${ }^{29}$

But none of these restrictions in the liberty of pseudo-citizens is regarded as important to the advocates of Bolsonarism. Bolsonaro's supporters are committed to present themselves as 'good' or 'model' citizens, and by implication they claim that their interests and the interests of the populist leadership are one and the same. The special bondage between the charismatic leader and the model citizens creates the impression that it is analytically impossible for a model citizen to lose her liberty when the liberty of a pseudo-citizen is restrained. The claim to exclusiveness of the model citizen entails that it is indifferent to them that the liberty of non-model citizens is denied, inasmuch as these pseudo-citizens lack the dignity-conceived as a special status that commands respect-which is proper of the model citizens alone.

Even though pseudo-citizens might suffer from state and private interference in their freedom, this interference is not treated as normatively relevant because pseudo-citizens, in this conceptual scheme, are not entitled to this freedom. Instead, they are conceptualized as traitors or enemies of the true people, i.e. as opponents to the valuable social forms that Bolsonarists are willing to defend.

More important than the pseudo-citizen's freedom, therefore, is the model citizen's liberty, especially his 'positive freedom' to be 'his own master'. Nevertheless, this idea is severely distorted. Isaiah Berlin's account of this positive freedom, for instance, claimed that it entails a right to be a 'thinking, willing, active being, bearing responsibility for [one's] choices and able to explain them by reference to [one's] own ideas and purposes'. ${ }^{30}$ On Berlin's account, the capacity to act as a rational agent is a central aspect of a person's liberty. Nonetheless, although the absence of control by others is part of what makes liberty a value, this kind of liberty does not include a liberty to act irresponsibly and in an arbitrary way.

Bolsonaro's conception of liberty redefines the idea of self-determination. To be free, for Bolsonarists, is to be free from any rational constraint. As we will attempt to explain in the next sessions, a Bolsonarist good citizen claims that this putative liberty to act in an arbitrary way is a valuable asset. She holds that freedom without

\footnotetext{
26 Rangel 2020.

27 Bulgarelli and Fontgaland, 2019.

28 Tommaselli 2020.

29 Human Rights Watch 2021.

30 Berlin 2002, 178.
} 
responsibility is a privilege entailed by the special status she claims only a good citizen can possess. She relies on Bolsonaro's authority to define who is entitled to this status, and once it is earned she no longer needs to reassess the moral legitimacy of one's actions.

Even though this freedom to act in an irresponsible way is different from any reasonable conception of liberty, it is presented as an aspect of the dignity of those who purport to be recognized as members of the 'true people', in Bolsonaro's sense.

Deprived of this liberty to act in accordance with what she intuitively perceives as a valuable pursuit, the model citizen's life becomes empty, since she loses the only thing that makes her pursuit more important than anyone else's. Instead of a model citizen, she becomes what she always feared: an equal citizen, with symmetric entitlements and obligations with other members of the community to which she belongs. In other words, without the model citizenship, which constitutes a special status, she cannot claim that her liberty takes priority over the liberty of pseudo-citizens and carries, once again, the burden to justify her actions. Without the special dignity derived from the adherence to the Bolsonarist project, she carries the weight of responsibility, which is precisely what liberty is about according to one of the most influent tradition in modern times: Kant's ethical theory, the analysis of which will be done in Sect. 5 .

\section{Bolsonarist Liberty and COVID-19 Denial}

A special test for Bolsonarism's account of positive liberty is provided by its responses to the epidemic of COVID-19. From the early stages of the pandemic, Bolsonaro openly minimized the danger imposed by the coronavirus and urged his supporters to ignore the sanitary recommendations of epidemiologists and scientific societies. Bolsonaro's responses to the pandemic of COVID-19 are based on a myriad of assumptions, which include not only empirical assumptions about the number of infections, death rates, economic consequences of the disease, availability of budgetary resources, risk of infection for ordinary individuals and specific groups, efficacy of vaccines, availability of vaccines, and other factors, but also normative assumptions that include considerations about the legitimacy of social distancing measures and restrictions imposed on economic activities, education, leisure, and religion. Although our analysis concerns primarily the normative assumptions, it is helpful to mention Bolsonaro's factual claims. Consider the following assumptions:

1. Most of the persons exposed to COVID-19 are asymptomatic and survive the virus with limited impact on their health.

2. COVID-19 affects predominantly elderly people and people who suffer from some pre-existing diseases.

3. People who do not belong to certain groups of risk are less susceptible to suffer serious harm in their health from an infection with COVID-19.

4. COVID-19 has a severe potential to cause economic losses and disturb other activities such as education, entertainment, and religious acts. 
5. COVID-19 kills in large scale and might put an end to hundreds of thousands lives in Brazil, but it is unlikely that they will kill people belonging to some specific groups.

These assumptions are widely accepted among Bolsonaro supporters. While assertion 1 , in the early days of the pandemic, was regarded as plausible by the scientific community, ${ }^{31}$ assertions 2 to 5 appear intuitive but there is still a lot of uncertainty about their accuracy.

Bolsonaro's propaganda machine, however, exaggerates the certainty of these assumptions and assures that the 'strong', 'young', 'brave', and 'ordinary' model citizens should not have any serious reasons for concern about the pandemic of Covid-19. In one of his most famous speeches in response to the global spread of the pandemic of COVID-19, Bolsonaro called the coronavirus disease a 'little flu' and voiced the following words in support of assumptions 2 to 5: 'In my particular case, because of my background as an athlete, I wouldn't need to worry if I was infected by the virus. I wouldn't feel anything or at the very worst it would be like a little flu or a bit of a cold'. ${ }^{32}$ Regardless of the evolution of the disease and the geometric increase in the death rates in the country, Bolsonaro consistently advocated that only a 'vertical isolation' should be adopted, limiting the effects of social distancing measures to people above 60 years old or 'highly vulnerable to COVID-19' ${ }^{33}$

While state governors and municipal authorities decreed social distancing measures, the president filed a complaint in the Federal Supreme Court to annul these regulations and issued federal decrees (which were later invalidated in judicial review), to strike down local restrictions on economic activities and circulation of persons. ${ }^{34}$ Moreover, part of his legal strategy was to 'harass, expose, threaten, and often prosecute scientists, physicians, journalists and university professors who issue opinions against the government'. ${ }^{35}$

This kind of strategy was aimed not only to intimidate opponents but also to provide support for the opinion that the risks of the pandemic are a threat only to 'others', instead of the true believer of Bolsonaro's speech. They are aimed, in addition, to treat the pandemic as a political rather than sanitary issue, ${ }^{36}$ compromising the rationality of the governmental action in response to COVID-19.

The failure of this approach was predictable since its assumptions are based more on ideology than scientific evidence. But this failure is due not only to bad science but also to an ethics. Bolsonaro and his ideologists refer prominently to moral

\footnotetext{
31 According to a research undertaken early in the pandemic, the rate of asymptomatic infections would be above $80 \%$ (Ing et al. 2020). Although these findings were contradicted by more numerous and statistically significative studies (e.g. Nogrady 2020), the thought that the large majority of the population would be unharmed by COVID-19 has been widely accepted by ordinary people in Brazil, especially among Bolsonaro's supporters.

32 Philips 2020.

33 Duarte 2020.

34 Ventura and Martins 2020, 74.

35 Bustamante and Meyer 2022; Escobar 2021.

36 Smith 2020.
} 
claims, which are normally grounded in the notion of 'freedom without responsibility' that we introduced in the previous section.

According to the ethical theory of Bolsonarism, the concepts of model citizen and liberty work in tandem. Liberty, they assume, is an unconstrained power attributable only to model citizens. The model citizen holds a special dignitary claim because her lifestyle has distinctive value. She lacks the vices that undermine the community's illiberal project and for this reason is held to possess a special kind of entitlement, which includes the power to prevent others from deviating from what she regards as a valuable and meaningful pursuit.

We believe that it is this relation between the model citizen and the conception of freedom without responsibility that explains Bolsonarism's responses to COVID-19. Bolsonarists sustain that they are entitled to ignore health measures and go on with their ordinary lives despite the global pandemic. This conception of freedom aims to de-legitimize the mechanisms of coercion employed by the state governments and the legislative branch, which were adopted to provide incentives to cooperate and prevent 'free riding' by those who might benefit from the health and sanitary measures to contain the virus but refrain from acquitting their own responsibility to collaborate.

When it comes to the normative arguments required to justifying restraints on an individual conduct when a shared collective action is strictly required for the common good, ${ }^{37}$ Bolsonaro resolutely refuses to endorse the reasons available to justify these restraints. He offers, instead, an authorization to refuse to cooperate and frames it as an ethical argument, which relies heavily on the notion of 'freedom without responsibility' stated above.

Bolsonarism's campaign against health measures was fierce. It advocated that any restrictions on economic activities were illegitimate. When asked about city curfews and restrictions on commerce and public transport, Bolsonaro responded with the motto: 'I lament the deaths, but we all are going to die one day'. In the same statement, he employed homophobic language to complain that 'Brazil must cease to be a country of faggots', and to advocate that the people should confront the virus 'with an open chest'. ${ }^{38}$ The state governors who adopted restrictions on commerce and economic activities during the worst days of the pandemic were classified as 'protodictators, ${ }^{39}$ whose social distancing measures were described as violations of 'economic freedom'. The left-wing governor of the state of Maranhão, Flávio Dino, for instance, was placed alongside the North Korean president Kim Jong-un and classified as a 'fat little dictator'. 40

By the same token, Bolsonarism resorts to a similar argument in its interpretation of the principle of 'medical freedom'. As the number of casualties raised, Bolsonaro forced upon the health system an 'early treatment protocol' in which medicines with no efficacy against COVID-19 (hydroxychloroquine and ivermectin) were widely

\footnotetext{
37 Tuck 2008, 109-115.

38 Gomes 2020.

39 Poder 360, 2020.

40 Fernandes 2021.
} 
distributed in the health system, with a potential to aggravate the condition of the patients. Given the influence of Bolsonarism's ethical doctrine among the medical class, Bolsonaro gained the official support of the Brazilian Federal Council of Medicine, which endorsed the 'right' of physicians to prescribe the drugs advertised by Bolsonaro as part of their professional autonomy or freedom to prescribe. ${ }^{41}$

Sometimes this freedom without responsibility is justified by an appeal to a special property, like belonging to a religious group. The General-Advocate of the Federal Government, André Mendonça, in defence of a submission that any measures adopted by city governments to restrict religious services during the pandemic would violate the constitutional right to 'freedom of religion', raised a claim to a special right of the members of the Christian religion, who were presented as 'in essence' bound to 'live in communion not only with God, but also with one's neighbour'. During a hearing before the Federal Supreme Court, Mendonça, who later would be nominated by Bolsonaro for a life-tenure as Justice in the same court, argued that 'true Christians' are 'always willing to die to secure their freedom of religion and worship'. 42

The radicalism of the latter assertion marks the degree of commitment to the conception of 'freedom of responsibility' we explain in this article, but the most salient point in Mendonça's reasoning is the assumption that Christianity works as a demarcation concept to fix the scope of protection for an alleged right to reunite thousands of persons in narrow indoor spaces during the most critical day of the pandemic, during the Eastern holiday of 2021, when rate of deaths in Brazil was above 4,000 people per day. This emotional argument in support of a special right of the members of the Christian religion, which sometimes is described as a kind of 'Christofascism', ${ }^{43}$ purports to provide an authoritative directive to discriminate the 'good' or 'model' citizens, who belong to a special class. While the freedom of scientists, journalists, academics, opposition parties, indigenous populations, LGBT + groups, and other persons is unprotected, ${ }^{44}$ any restriction in the model citizen's interests, temporarily and geographically circumscribed as it might be, is described as tyranny or a severe violation of fundamental rights.

Bolsonarism attacks the legitimacy of local laws by means of an indirect attack on the claim to reciprocity that stands at the core of the modern conception of freedom. As Hart explained (to acknowledge the possibility of coercive enforcement of our responsibility to prevent an individualistic attitude when a coordinated behaviour is required), 'when a number of persons conduct any joint enterprise according to rules and thus restrict their liberty, those who have submitted to these restrictions when required have a right to a similar submission from those who have benefited by their submission' ${ }^{45}$ Hart places a claim to fairness and reciprocity at the heart of

\footnotetext{
41 Conselho Federal de Medicina 2020.

42 Oliva 2021.

43 Py 2020.

44 In effect, Mendonça, acting as Minister of Justice, instructed the federal bureaucracy to punish academics (including epidemiologists) who openly challenged Bolsonaro's denialism, creating a scenario of harassment and threats of prosecution for scientists and university professors. Escobar 2021.

45 Hart 1955, 185.
} 
the moral justification for coercive laws, which conceives citizens as equally free in a typical liberal sense. Part of any account of legitimacy requires an 'equal distribution of restrictions and so of freedom'. ${ }^{46}$ The idea of equal freedom plays a fundamental explanatory role. Bolsonarism, however, undermines any liberal conception of freedom because it assigns a 'special status' to a particular group of citizens, which coincide with the most committed advocates of Bolsonarism. ${ }^{47}$

Bolsonarism openly denies the liberal claim to reciprocity. Its arguments are addressed to the model citizens, who perceive themselves as belonging to a special group. The general equality underlying the liberal notion of freedom is the most persistent target of Bolsonarism, as we are going to examine in sequence.

\section{Kant's Ethical Theory on Its Head}

Kant's account of freedom is based on the enlightenment ideal that we must live up to a non-heteronomous understanding about the right course of action for our lives, 'without direction from another'. ${ }^{48}$ We act rationally when we rely on an autonomous assessment instead of submitting ourselves to a heteronomous view. Autonomy, for Kant, is the 'supreme principle of morality', but it authorizes only that one act in a way that the maxim of one's choice is acknowledged and willed as a universal rational law. ${ }^{49}$ It depends, therefore, on our capacity to act according to pure reason and liberate ourselves from our urges, selfish interests and irrational preferences; 'all moral concepts have their seat and origin completely in a priori reason'. ${ }^{50}$ One is autonomous only for as long as one acts based on a moral law that is ascertainable through rational judgments. One should act for duty, i.e. 'respect from moral law'. 51

We believe that Kant's ethical theory provides a sound point of departure to understand why Bolsonarism advances a delusive conception of freedom, because this purported account of freedom is in straight opposition to Kant's ethical thought. For Kant, freedom is the source of our rational will when it is "efficient independently of alien causes determining if'. ${ }^{52}$ Human dignity is a feature of every human and our liberties must be conceived of as equal and universal. Our respect for humanity entails a respect not only for our own life but for every other human life as well. To recognize one's dignity is to postulate a universal law that regards this dignity as a common entitlement, and to attribute to everyone a standing to use one's rational faculties to determine the content of the moral law. We are entitled only to the freedom we can recognize in others, and we can hold others accountable only to the norms to which we submit and endorse.

\footnotetext{
46 Ibid, 190-191.

47 See, on the massive mutual support between evangelicals and Bolsonarism, Kibuuka 2020.

48 Kant 1784/1996, 17.

49 Kant 1785/1996, 89.

50 Ibid., 65.

51 Johnson and Cureton 2021.

52 Kant 1785/1996, 94.
} 
When it comes to legal authority, the reason for its political legitimacy is the need to make this liberty available to everyone. Freedom is, for Kant, 'the only innate right'. ${ }^{53}$ Political authority is rationally postulated because it is needed to preserve everyone's freedom to act in accordance with universal laws. Freedom as 'independence from being constrained by another's choice' provides the basis for state action because we require a political power to prevent one person from hindering the freedom of others. ${ }^{54}$ Kant thinks that the state is not impediment to freedom but is a means to freedom'. 55 'State action that is a hindrance to freedom can, when properly directed, support and maintain freedom if the state action is aimed at hindering actions that themselves would hinder the freedom of others'. ${ }^{56}$

All humans are free because all humans are rational beings, who share a responsibility to acknowledge rational principles and conduct their lives under their domain. Everyone should be regarded as equal because everyone possesses the ability to give herself the content of the moral law. At the centre of Kant's ethics lies the categorical imperative, which establishes that one should only act according to a maxim that can be accepted and willed as a universal law. This implies a commitment to reciprocity and a responsibility to figure out the entitlements of other persons that this commitment entails. Freedom and responsibility are two faces of the same coin.

To be free, on Kant's ethics, is to submit to reason. It is to place oneself under its authority, to make oneself responsible and accountable to others in light of the act of undertaking this commitment. ${ }^{57}$ One's own freedom is violated, therefore, when one acts according to prejudice, or whim, or bias, or caprice. Freedom, in Kant's ethical thought, is the opposite of arbitrary action or action based on personal interest or irrational desire. Even though respect for one's autonomy requires respecting one's will, we are entitled to will only what we can present as reason-giving. In other words, "we can justify claims we make on others as free and rational only by acknowledging an equal standing all free and rational agents have to make such claims ${ }^{58}$ To be free is to be responsible and accountable because freedom requires placing oneself under the domain of universal rational principles.

It is often argued that this requirement is not incompatible with the thought that reason gives us a plurality of options or that there might be incommensurable paths open to a rational agent, since our rationality can give us a 'latitude' of reasons in which whatever decision we adopt will be regarded as an intelligible and admissible path. ${ }^{59}$ Nonetheless, despite the plausibility of this claim, our commitment to rationality and our respect for humanity imply a duty of impartiality. In the cases in which our will or our desire can be the source of new reasons for action, "what explains why an agent's own will can give him reasons is inextricably linked to why his will

\footnotetext{
53 Kant 1797/1996, 393.

54 Ibid., 393.

55 Rauscher 2017.

56 Ibid.

57 Brandom 2009, 63.

58 Darwall 2013, 95.

59 Raz 1999, 105.
} 
can give them also to others' ${ }^{60}$ Equality of options and reciprocity of respect for anyone's choices are at the heart of a person's standing to act as she desires. If your will or your desire is admitted to play a role in your life, providing you with new reasons for action, it must be a rational will that can be adopted by any other rational person. A constitutive aspect of our freedom is that it depends on our dignity, which follows from our human condition and our standing to judge and act in accordance with universal laws.

Bolsonarism places, therefore, Kant's ethics on its head. While Kant conceives dignity as a universal entitlement, which implies an equal standing and a principle that all humans are worthy of respect, Bolsonarism is based on a special status and a claim to partiality toward the fellow model citizens. It entails, in addition, that this partiality is arbitrary, since it is grounded in a priority of feeling over reason, or of one's affection to the populist leader over one's duty to submit to a universal law. ${ }^{61}$ Particular laws, or principles that apply only to a special class of citizens, are a central element of Bolsonarism.

It is also crucial to Bolsonarism that it breaks the relationship between rationality and freedom. Bolsonarist freedom is redefined as a standing to act in complete absence of constraint. A model citizen who earns the approval of Bolsonaro is free to the extent that she can submit to her own urges and irrational desires. 'Arbitrary action' and 'freedom' become indistinguishable, since freedom is now decoupled from rational action and does not obtain through the endorsement of enlightenment principles. To constrain one's inclinations is not a presupposition of freedom, but a violation of it instead.

If you feel that you are special, therefore, or that your neighbour is inferior because he commits to an alternative religion, ethnic community, or social group, it is part of your freedom to fight for your special status, even if this fight implies coercion, violence or other types of harm to those belonging to the competing social group.

We can observe, therefore, that Bolsonarism endorses an ideal of dignity which applies only to a special group. It is based on a hierarchical ranking of persons in which those in the highest positions have the privilege of having rights without responsibility. Given that my dignity stems from my special relationship with the populist leader, I owe nothing to strangers and pseudo-citizens, given that I do not acknowledge them as rational beings entitled to their own judgments of what the principles of rationality entails. I do not treat them as free because I do not treat their judgments as authentic, and I do not regard them as worthy of respect. My freedom is not reciprocal, because I do not place myself in the same level as everyone else. The link between entitlements and duties is broken, undermining the rational connection between freedom and responsibility, which lies at the core of modern ethical thought.

\footnotetext{
60 Darwall 2013, 94.

61 As we will show in Sect. 6, this claim to partiality should not be confused with the arguments of moral communitarianism, since it is arbitrary and unconstrained instead of constrained by communitarian values and practical reasons. We thank an anonymous reviewer of Jus Cogens for turning our attention to this important point.
} 


\section{Atomism and Communitarianism}

Given the sharp contrast with the Kantian tradition, one might think that communitarianism is a moral doctrine underlying Bolsonarism. Many forms of populism are partly justified by arguments that communitarian thinkers adduce against liberalism. The core assumption of communitarianism is that moral obligations, values, and rights must be interpreted according to shared practices and understandings, rather than abstract and universal norms. Instead of building a theory of justice from impartial principles of justice, we should reach out for our community's own culture, history, and traditions, attributing a prominent importance to the social relationships and common goods to which we resort in order to make sense of our ethical world. We must be able to find these goods in our own political association, instead of appealing to Archimedean arguments that philosophers find in a transcendental domain. Our political judgments should avoid, for thinkers like Alisdair MacIntyre, Charles Taylor, Michael Walzer and others, abstract entities like 'social contracts' or metaphysical categories that intend to isolate the interpreter from her interpersonal relationships, religion, and cultural bonds. ${ }^{62}$ On the communitarian story, we must seek to understand our values with a more local interpretive framework.

A famous argument pressed by some communitarians against liberal moral and political thinkers is the argument against atomism, which offers an interesting standpoint to compare this theory with Bolsonarism. According to Taylor, liberalism fails because it treats mankind as 'self-sufficient outside society', instead of political animals in an Aristotelean sense. ${ }^{63}$

It is interesting to observe, in this matter, that the best responses to this argument do not deny the relevance of interpersonal relationships, common goods and attachments. They reject, instead, that political liberalism is necessarily opposed to it. A common reply, for instance, claims that even if the charge of atomism works against libertarians like Robert Nozick, it fails to provide a serious challenge to authors like John Rawls, who considers with attention the 'psychological and social conditions that facilitate the formation of liberal selves committed to justice'. ${ }^{64}$ One can find, in effect, liberal moral philosophers who explicitly aim to combine a commitment to personal autonomy and freedom with a commitment to a classical conception of practical reason that emphasizes fidelity to common goods and to the agent-relative reasons that arise from the attachments we develop to some interpersonal relationships. Joseph Raz, for instance, believes that a sound account of freedom must construct a theory of responsibility that emerges precisely from the value of these attachments. The meaning of what we regard as valuable arises, for him, in the following way:

\footnotetext{
$\overline{62}$ See Walzer 1994; Taylor 1989; MacIntyre 1984.

63 Taylor 1985, 200.

${ }^{64}$ Bell 2020.
} 
Meaning comes through a common history, and through work. They make the object of one's attachment unique. You will not be surprised that meaning comes with responsibility and through responsibility. By assuming duties we create attachments. Duties and special responsibilities, not rights, are the key to a meaningful life, and are inseparable from it. In denying our duties we deny the meaning of our life.

Why duties rather than rights? Because duties involve responsibilities and, therefore, engage our lives in a way which rights do not. We are passive regarding our rights, we are recipients so far as they are concerned. ... Duties are reasons for action. ... Our duties define our identities more profoundly than do our rights. They are among the primary constituents of our attachments, among the fundamental contributors to meaning in our life. ${ }^{65}$

This kind of reasoning is an interesting attempt to combine the core assumptions of liberal thinkers (its emphasis on autonomy and responsibility) with some commitments of communitarianism (the value of attachments and interpersonal relationships). It convincingly illustrates that anti-liberal politicians are usually wrong when they claim that appealing to communitarian ethics is enough to dismantle the achievements of political liberalism, or to suggest that liberal values must be pushed to the corner.

Nonetheless, the usual strategy of populists is to exaggerate the tension between liberal and communal values and ground their authority in the latter without the limits of the former, as the Hungarian Prime Minister Victor Orbán argued in a famous speech:

The Hungarian nation is not a simple sum of individuals, but a community that needs to be organized, strengthened and developed, and in this sense, the new state that we are building is an illiberal state, a nonliberal state. It does not deny foundational values of liberalism, as freedom, etc.. But it does not make this ideology a central element of state organization, but applies a specific, national, particular approach in its stead. ${ }^{66}$

Orbán attempts, in this address, to forge a collective identity 'by means of historical, cultural, and identitarian elements (the nation)', even though these elements are misrepresented because the populist leader regards as part of the majority just the part of the people that he regards as 'one of us'. ${ }^{67}$

Although there is a similarity between this discourse and the Bolsonarist idea of 'model citizen', we believe there is a sharp contrast between Bolsonarism and communitarianism. As an anthropologic study shows, Bolsonarists come from very diverse social groups (sexist males, gun users, nerds, gamers and haters, military, anti-feminist women, mothers resentful against affirmative action in universities, conservative gays, right-wing students concerned with

\footnotetext{
65 Raz 2001, 20-22.

66 Orbán, quoted in Blokker 2018, 120.

67 Blokker 2018, 120.
} 
Marxist ideology and indoctrination, supporters of meritocracy, libertarians who support the free-market, digital influencers, religious leaders, evangelicals, and so on). ${ }^{68}$ Bolsonarists form a very fragmented collectivity that is kept together only because of the individualist aspect of its ethics. Although people think of themselves as model citizens, they lack a common identity or relationships among themselves. The model citizen is defined negatively, by mere absence of some vices, such that there is little that they must share. In effect, Bolsonaro is presented differently to each of these groups, with which he communicates through direct interactions in social networks. What they share is an extremely individualist concept of liberty, instead of common goods that place limits on what a person can will.

While communitarians assume that communal relationships create special responsibilities that allow one to be partial toward one's community, Bolsonarists do not suppose that their attachment to Bolsonarism requires the undertaking of novel responsibilities. An important part of Bolsonaro's promise to his followers is a liberty that is independent from the interpersonal duties and responsibilities that hold among the members of community. 'Freedom without responsibility' is not derived from special duties, which hold among members of a community, but rather stems from a utopic idea of liberty without constraint.

It does not come as a surprise that Taylor's charge of atomism holds with much greater force against Bolsonarists than it does against any type of liberal theory, for Bolsonarists claim to have a liberty to act in an arbitrary way. While communitarians presuppose a set of common goods and an ethics of attachment that allows the community to render its members accountable to the community, Bolsonarism promises its followers an unconstrained freedom that makes them accountable to no one, including Bolsonaro, given that their ideology assumes there can be no conflict between their own interests and the interests of their leader.

\section{Breaching the Social Contract}

Bolsonarism's doctrine of freedom may appear bizarre, but it is not entirely unfamiliar. Its notion of freedom shares some features with one of the most influential political theories in history, which is Thomas Hobbes's political philosophy. According to Hobbes, liberty can be defined as 'absence of opposition', i.e. 'impediments to motion', and is a concept that 'may be applied no less to irrational, and inanimate creatures, than to rational'. ${ }^{69}$ Hobbes sees no contradiction between 'freedom' and 'necessity', ${ }^{70}$ and sustains that under the jus naturale (or 'right of nature') every man has the liberty to use his power, 'as he will himself, for the preservation of his

\footnotetext{
68 Kalil 2018.

69 Hobbes 1651/1998, 139.

70 Ibid., 140.
} 
own nature; that is to say, of his own life'. ${ }^{71}$ A freeman is a person who is not hindered from doing all things that, 'by his strength and wit', he has a will to do. ${ }^{72}$

The difference between Hobbes and Bolsonarism's account of freedom becomes more apparent, however, when we consider Hobbes's accounts of human nature and natural law. Hobbes's account of human nature purports to be a descriptive anthropology, but it is based on an egalitarian assumption that Bolsonarists reject. It is a central assumption in Hobbes's account of nature that all men were made equal, both 'in the faculties of the body and mind'. ${ }^{73}$ This equality is the source of men's capacities for war and of men's fragility or vulnerability, for no man can be said to be free from the risk of being subjugated or killed by one's equal.

It is because of this natural equality and fragility that, in addition to the "natural right' or liberty to do as one can and will, Hobbes postulates a 'natural law', which is composed of precepts or general rules 'found out by reason', that establish a prudential principle of self-preservation. The 'fundamental law of nature', therefore, is the general rule that 'every man ought to endeavour peace, as far as he has hope of obtaining it; and when he cannot obtain it, ... he may seek, and use, all helps, and advantages of war'. ${ }^{74}$ This fundamental law, however, is presented by Hobbes not as a matter of moral entitlement, in the modern sense of a 'just' entitlement that is symmetrical to one's obligation to respect one equal's dignity. It has a strictly prudential status, and it recommends the gathering of men to create a civil law that is born out of the Leviathan.

Reason recommends men to adhere to a social contract because reason recommends men to give up their absolute freedom and exchange it in order to emancipate themselves from the arbitrariness of other men. Liberty is not something that, according to Hobbes, one is entitled to retain. It is a freedom to act in any possible way, including some abhorrent ways that emerge from the techniques of war, and there is no moral compulsion to retain it. A contract, for Hobbes, is a 'mutual transferring of right', ${ }^{75}$ and when men are advised by reason to contribute to create the Leviathan they are advised to transfer their natural freedom, which is the kind of freedom Bolsonarists hope to preserve.

Here lies an important difference between a Hobbesian commonwealth and Bolsonarist populism. While Hobbesian covenants give up the right to govern themselves in exchange for the protection of a newly created absolute power, ${ }^{76}$ Bolsonarists share something like Rousseau's promise that they will live under a 'general will' in which they remain just as free as before. Through the mechanism of identification with the populist leader, Bolsonarists are led to believe that they are in charge, and that they are endowed with some part of Bolsonaro's authority. As we argued in Sect. 2, Bolsonaro presents himself as an ordinary man who has the same

\footnotetext{
71 Ibid., 51.

72 Ibid., 139.

73 Ibid., 82.

74 Ibid., 87.

75 Ibid., 88.

76 Ibid., 114.
} 
characteristics, including not only the abilities and values but also the fragilities, simplicity, bad manners, ignorance, and urges of the bulk of model citizens. The ordinary model citizen sees Bolsonaro's ascension to office as her own triumph. Bolsonarists take themselves to be free because they are deputies of their populist leader, i.e. some kind of private officiality that is granted the power to enforce the lifestyle of the model citizenry. ${ }^{77}$ There is no Leviathan because there is no need for a central and unified power. Bolsonaro nourishes his powers in a 'pre-social contract' kind of natural right. He portrays the freedom to act as one will, including when one is driven by an irrational preference, as an important value, as some central aspect of one's dignity, and as a power that one has a legitimate claim to retain.

Bolsonaro has in common with Hobbes the defence of an absolute power, nonetheless. But he claims that there are others like him with a smaller part of that power, and treats them as 'his army'. He blesses these private absolutists, that are co-authors of his enterprise, with his protection; and gives them a license to fight for it. Bolsonarist freedom only exists, therefore, in a divided society. It depends on fragmentation, and it argues that civil war is a small price to pay, because Bolsonaro promises his followers eternal victory in any civil war. He gives his followers a right to fight while promising protection against backlash. This sounds like an irrational manipulation because it is. But one must concede at least that Bolsonaro is consistently committed to his irrationalism. He never purported to ground his freedom on reason, as we, rationalists and non-Bolsonarists, would expect.

\section{The Putative Attractiveness of Bolsonarist Freedom}

'I'll pay the psychoanalyst's bill, so I'll never again have to learn who I am' ${ }^{78}$

The comparison between Bolsonarism and the concepts of freedom encountered in the Kantian, communitarian, and Hobbestian traditions is helpful to understand the attractiveness of the idea of freedom without responsibility. The common element of the accounts offered by Kant, the communitarians, and Hobbes is that they are in essence intellectually demanding, in the sense that they require a rational response to the reasons for action provided by the notion of freedom.

If we read these conceptions in light of the contemporary developments on the nature of human thinking provided by an influent literature in behavioural economics, psychology, neuroscience, and other disciplines, the traditions examined in the previous three sections can be classified as instances of 'slow' or 'deliberative' thinking, rather than 'fast' or 'intuitive' responses. The Bolsonarist reaction to any concrete assessment of the value of freedom, as applied to determine the course of

\footnotetext{
77 In several of his speeches, Bolsonaro refers to the military forces as 'my army', to mark a private, rather than official, relationship between himself and the armed forces (The Economist 2021). Another revealing point, which found support of the evangelical churches (Kibuuka 2020), is the ideology of violence and proliferation of fire weapons among 'good citizens' (Paschoal 2020).

78 'Eu vou pagar a conta do analista, para nunca mais ter que saber quem eu sou'. Cazuza 1988.
} 
action to be adopted in a given case, can be described as a typical case of 'affect heuristics', i.e. of the kind of 'judgements and decisions ... guided directly by feelings of liking and disliking, with little deliberation or reasoning'. ${ }^{79}$

According to the psychological terminology proposed by Stanovich and West, ${ }^{80}$ the human mind can respond to a challenge of inquiry through two distinctive modes of thinking, which have been conventionally designated as 'System 1' and 'System 2'. While System 1 'operates automatically and quickly, with little or no effort and no sense of voluntary control', System 2 'allocates attention to the effortful mental activities that demand it, including complex computations. The operations of System 2 are often associated with the subjective experience of agency, choice and concentration'. 81

The capabilities of System 1 include both the 'innate skills that we share with other animals' and the 'mental activities that become fast and automatic through prolonged practices, ${ }^{82}$ When I rely on System 1 to make a decision or adopt a particular course of action, I follow the natural response that immediately comes to my mind. The mental events belonging to System 1, for Kahneman, 'occur automatically and require little or no effort'. ${ }^{83}$

A decision based on System 2, in turn, requires a 'continuous monitoring' of one's own behaviour, which includes both a decision to remain focused and attentive, and a mental effort of self-control. ${ }^{84}$ Given the dependence of freedom on responsibility, Kantian and communitarian accounts of liberty make the pursuit of freedom inherently dependent on one's voluntary and disciplined engagement with the modes of thinking appropriate to System 2. A supporter of Kantian or communitarian ethics will require an intensive mental activity not only to act in accordance with what liberty entails, but even to understand what liberty requires. While Kantians will place themselves under the authority of a universal rational law, communitarians will be asked to commit to values embedded in the concrete practices in which they participate. In both cases, however, a rationally justified decision is described as incompatible with an arbitrary action, inasmuch as it implies a disciplined exercise of practical reasoning.

In a similar way, Hobbesian justifications of political legitimacy will need both an indirect usage of System 2 and a counterintuitive decision to compromise our 'natural' freedom. Although Hobbes's political philosophy does not define freedom in a way that requires a rational use of one's mental abilities, the choice to depart from the state of nature and the argument to justify political obligation require an intensive mental activity from the part of a rational agent. The argument for political authority is based on a practical reasoning undertaken by System 2. Furthermore, that practical reasoning leads to a decision to renounce the natural freedom that men

\footnotetext{
79 Kahneman 2011, 12.

80 Stanovich and West 2000.

81 Kahneman 2011, 20-21.

82 Ibid., 21-22.

83 Ibid., 21.

84 Ibid., 31-38.
} 
and women enjoy in the state of nature, which is an assumption that advocates of Bolsonarism are resolutely committed to reject. The burden imposed by Hobbestian authority on Bolsonarists is even greater than that of Kantian and communitarian accounts, since it inevitably arrives at the conclusion that they rejected at the outset.

The Bolsonarist account of 'freedom without responsibility' appears attractive because of two intuitive dispositions. First, it is presented as a default position that comes to mind when humans resort exclusively to System 1. Second, it discharges one from the uncomfortable task of self-examination, challenging one's convictions with the machinery of reason.

Freedom without responsibility emerges as a non-reflective, intuitionistic, or natural understanding of liberty, which assigns to those who are not committed to control their irrational responses an illusion of entitlement to their biases, whimsical prejudices, and unreflective judgments. Irrational as it may seem to those accustomed to the language of 'liberal rights' and 'public reason', in Rawls's terminology, freedom without responsibility is attractive to the lazy or to those that lack an interest in assessing themselves.

In addition, 'freedom without responsibility' naturally places the agent in the comfortable position of not being accountable or responsible for her deeds. It gives her a license to act as she pleases. In the most pathological cases, which are far from rare given the aggressiveness that characterize Bolsonaro's political practice, 'freedom without responsibility' becomes attractive because the agents deliberately 'do not want to know' what their duties entail, ${ }^{85}$ or do not want to pay the cost required to enjoy the freedom they affirm to deserve. Unlike the case of the lazy actor who does not bother to look harder and considerately to determine what she should do, this second sense of freedom without responsibility enables a strategic use of selfignorance, i.e. authorizes one to treat 'ignorance as an excuse to over-indulge in pleasurable activities that may be harmful to one's future self' ${ }^{86}$ or (we add) to others that may be impacted by the consequences of her deeds.

As Cass Sunstein argued in an intriguing book on the attractiveness - and circumstantial legitimacy — of refusing to acquire non-useful (or even harming) information, economics scholars usually present two reasons for deciding to know or not-know certain things: first, the capacity of the information to produce "positive feelings' like 'joy, delight, amazement, or relief'; and, second, the 'instrumental value' of such information. ${ }^{87}$ Although there may be also broader (and more ethically significative) reasons to acquire knowledge, like the pursuits we make in order to 'have a fuller or more meaningful life, ${ }^{88}$ the usual utilitarian reasons-which Sunstein classifies as 'hedonistic' and 'instrumental' - seem to be in play in the advocacy of unconstrained liberty provided by Bolsonarism.

Since instrumental reasons are never ultimate reasons (inasmuch as they are means to goals which require further justification), our explanation of the apparent

\footnotetext{
${ }^{85}$ Ulmann-Margalit 2017; Sunstein 2020

86 Thunström et al 2016.

87 Sunstein 2020, 14.

88 Ibid., 8.
} 
attractiveness of Bolsonarist freedom must be found almost exclusively in hedonistic reasons. We can think of no other reason to endorse Bolsonaro's concept of 'freedom without responsibility' than prioritizing what Jeremy Bentham has described as a sinister interest, i.e. the kind of selfish interests that one pursues 'at the expense of the interests of others' ${ }^{89}$ Only a reluctance to assess oneself or to include in one's practical reasoning considerations that make sense of the commitments we must undertake in order to claim a right to freedom (i.e. to take responsibility for one's action) can lead one to endorse Bolsonaro's putative concept of freedom.

Consider a white male model citizen in his thirties or forties, with middle-class income, no pre-existing diseases, and no particular form of vulnerability, but who is likely to impose sacrifices in his social and economic life if he follows social distancing requirements and obeys the health authority instructions to stay at home.

If he accepts the five empirical assumptions stated in the beginning of Sect. 4, it would be natural to conclude that health authorities are instructing him to impose economic sacrifices and to abstain from performing activities that might be regarded as important for him. He is asked to avoid spreading a disease that will produce an indirect impact in his life. It might kill some people he knows or likes, or it might put an end to the resources of the health system, with a heavy social cost. But it is unlikely, in his judgment, that it will affect him directly. He has empirical reasons to believe he is not going to die, and his reason-scepticism prevents him from relying on the promise that the social distancing measures are going to result in something beneficial for himself.

If you ask him to defer to the COVID-19 regulations, you will be asking him to give up part of his 'freedom', understood as a personal option to do as he pleases. You will be asking him to sacrifice this desire in favour of the interest of others, or perhaps some abstract goals, such as the survival of a public health system, or thirdparty rights, such as the lives of elderly people.

If he is a committed Bolsonarist, he is likely to think that sanitary recommendations are trying to impose a sacrifice on him to protect the 'pseudo-citizens' who do not conduct their lives in the way that he, as a model citizen, believes we should do. In fact, most of the people who ask for vaccines, social distancing, masks, and so on, are the same people who require us to constantly resort to System 2 and to demystify the rhetoric that the model citizen proudly endorses. Most of the scientists, university professors, epidemiologists, journalists, state governors, political scientists, foreign experts, biologists, and other citizens who press for these sacrifices are, in the mind of the model citizen, the opposite of a 'law-abiding' citizen or virtuous person that, like him, have received the approval of Bolsonaro and his like. To ask this midthirties white 'model citizen' to give up his privileged social status and force him to take responsibility to contain the disease amounts to asking him to give up his liberty. For he understands 'liberty', as we have seen, as decoupled from responsibility.

${ }^{89}$ Postema 2019, 43. 


\section{Conclusion}

Part of Bolsonaro's power comes from an anti-liberal rhetoric that can be traced to contemporary forms of illiberalism, i.e. a reason-skeptic ideology that purports to undermine liberal democracies and rule according to the charismatic legitimacy of a populist leader. His concept of liberty can be described as analogous to Hobbes's political philosophy in an important sense. Liberty, for Bolsonarism, is the absence of impediments to motion. It includes a freedom to act irrationally and lacks any form of constraint. His aggressive rhetoric raises a moral claim to freedom without responsibility, which becomes attractive to his followers because it relieves them from the burdens that emerge from more modern accounts of liberty, which are based on constraints imposed by reason, as in Kant's moral philosophy, or basic goods accepted in a community. Bolsonaro's ethical doctrine is at odds both with Kant's submission of will to reason, and with communitarianism's eschewal of individualism. It deviates from Hobbes, however, because it treats this freedom without responsibility as a positive value, i.e. as something endowed with more than instrumental value. His response to COVID-19 explores this conception and liberates agents both from rational constraints and from the associative obligations that emanate from community-based relationships. It is marked by individualism, negligence and indifference to other humans' wellbeing and lives. But this does not make it less a moral claim when it comes to analysing its nature, as we attempted to do in the paragraphs above.

\section{References}

Albertazzi, D, McDonell D (2008) Introduction. In Albertazz D, McDonell D (eds), Twenty-First Century Populism. Palgrave, Basingstoke, pp 1-11

Andrés R (2019) Jeitinho sobre Rodas: o bolsonarismo e o trânsito. Piauí 154. https://piaui.folha.uol.com. br/materia/jeitinho-sobre-rodas/. Accessed 10 August 2021

Bell D (2020) Communitarianism. In: Zalta N (ed), The Stanford Encyclopedia of Philosophy, Fall 2020 edn. https://plato.stanford.edu/archives/fall2020/entries/communitarianism. Accessed 10 August 2021

Berlin I (2002) Two Concepts of Liberty. Liberty, Incorporating 'Fours Essays on Liberty.' OUP, Oxford, pp 166-217

Blokker P (2018) Populist Constitutionalism. In: De la Torre C (ed) The Routledge Handbook on Global Populism. Routledge, New York, pp 113-128

Brandom R (2009) Reason in Philosophy: Animating Ideas. Cambridge, Mass, Belknap

Bulgarelli L, Fontgaland A (2019) Violência Contra LGBT+ nos Contextos Eleitoral e Pós-Eleitoral. Gente e Números 2019. Available at http://violencialgbt.com.br/. Accessed 10 August 2021

Bustamante T, Meyer EPN (2022) Brazil: COVID-19, illiberal politics and the rule of law. In: Donald A, Grogan J (eds) The Routledge Handbook on Law and the Covid-19 pandemic. Routledge (forthcoming)

Casullo, ME (2018) The Populist Body in the Age of Social Media: A Comparative Study of Populist and Non-Populist Representation. International Political Science Association Conference, 2018. https:// archivos.juridicas.unam.mx/www/site//index/paper-dra-flavia-freidenberg-1557.pdf. Accessed 10 August 2021

Cazuza (1988) 'Ideologia' (songtrack). In: 'Ideologia', PolyGram

Conselho Federal de Medicina (2020) Parecer CFM n. 04/2020. https://sistemas.cfm.org.br/normas/visua lizar/pareceres/BR/2020/4. Access 10 August 2020 
Darwall S (2013) Morality, Authority, and Law: Essays in Second-Personal Ethics. Oxford University Press, Oxford

Duarte TR (2020) Ignoring scientific advice during the Covid-19 pandemic: Bolsonaro's actions and discourse. Latin American Science, Technology and Society, Tapuya. https://doi.org/10.1080/25729 861.2020 .1767492

Escobar H (2021) 'A Hostile Environment': Brazilian Scientists Face Rising Attacks from Bolsonaro's Regime. Science, 7 April 2021, https://www.sciencemag.org/news/2021/04/hostile-environmentbrazilian-scientists-face-rising-attacks-bolsonaro-s-regime. Accessed 10 August 2021

Fernandes T (2019) Bolsonaro Defends Child Labor. Folha de São Paulo, 5 July 2019, https://www1. folha.uol.com.br/internacional/en/brazil/2019/07/bolsonaro-defends-child-labor.shtml. Access 10 August 2020

Fernandes A (2021) Bolsonaro chama governador do Maranhão de 'gordinho ditador'; Dino responde. Estado de Minas, 21 May 2021, https://www.em.com.br/app/noticia/politica/2021/05/21/interna_ politica,1268934/bolsonaro-chama-governador-do-maranhao-de-gordinho-ditador-dino-responde. shtml. Access 10 August 2020

Ferrante L, Fearnside PM (2019) Brazil's new president and 'ruralists' threaten Amazonia's environment, traditional peoples and the global climate. Environ Conserv 46:261-263. https://doi.org/10.1017/ S0376892919000213

Franco, BM (2018) Em discursos, Bolsonaro já exaltou milícias e grupos de extermínio. O Globo, 14 Oct, 2018. https://blogs.oglobo.globo.com/bernardo-mello-franco/post/em-discursos-bolsonaro-jaexaltou-milicias-e-grupos-de-exterminio.html. Access 10 August 2021

Garrard G (2021) Illiberalism and opposition to enlightenment. In: Sajo A, Uitz R, Holmes S (eds) The Routledge Handbook on Illiberalism. Routledge (forthcoming)

Gomes, PH (2020) Brasil tem de deixar de ser 'país de maricas' e enfrentar pandemia de 'peito aberto', diz Bolsonaro. G1, 10 Nov, 2020. https://g1.globo.com/politica/noticia/2020/11/10/bolsonaro-dizque-brasil-tem-de-deixar-de-ser-pais-de-maricas-e-enfrentar-pandemia-de-peito-aberto.ghtml. Accessed 10 August 2021

Hart HLA (1955) Are There any Natural Rights? The Philosophical Review 64:175-191. https://doi.org/ $10.2307 / 2182586$

Hobbes T (1651/1998) Leviathan, Gaskin, JCA (ed). Oxford University Press, Oxford

Human Rights Watch (2021) World Report / Brazil: Events of 2020. https://www.hrw.org/world-report/ 2021/country-chapters/brazil. Accessed 10 August 2021

Ing AJ, Cocks CC, Green JP (2020) COVID-19: in the footsteps of Ernest Shackleton. Thorax 75:693694. https://doi.org/10.1136/thoraxjnl-2020-215091

Johnson R, Cureton A (2021) Kant's Moral Philosophy. In: Zalta EN (ed), The Stanford Encyclopedia of Philosophy (Spring 2021 Edition). https://plato.stanford.edu/archives/spr2021/entries/kant-moral/. Accessed 10 August 2021

Kalil IO (2018). Quem São e no que Acreditam os Eleitores de Jair Bolsonaro. Fundação Escola de Sociologia e Política de São Paulo. https://www.fespsp.org.br/upload/usersfiles/2018/Relatório\% 20para\%20Site\%20FESPSP.pdf . Accessed 10 August 2021

Kant I (1784/1996) Answer to the question 'What is Enlightment?'. In: Guyer P, Wood A (eds), Immanuel Kant: Practical Philosophy. Cambridge University Press, Cambridge, pp 11-14

Kant I (1785/1996) Groundwork of the Metaphysics of Morals. In: Guyer P, Wood A (eds), Immanuel Kant: Practical Philosophy. Cambridge University Press, Cambridge, pp 37-108

Kant, Immanuel (1797/1996). 'The Metaphysics of Morals'. In: Guyer P, Wood A (eds), Immanuel Kant: Practical Philosophy. Cambridge University Press, Cambridge, pp 353-604

Kahneman D (2011) Thinking Fast and Slow. Straus and Giroux, New York

Kibuuka BGL (2020) Complicity and Synergy Between Bolsonaro and Brazilian Evangelicals in COVID19 Times: Adherence to Scientific Negationism for Political-Religious Reasons. International Journal of Latin American Religions 4:288-317. https://doi.org/10.1007/s41603-020-00124-0

Mafei R, Bustamante T, Meyer EPN (2021) Brazil: From Antiestablishmentarianism to Bolsonarism. In: Sajo A et al. (eds), Routledge Handbook on Illiberalism, New York, forthcoming

McIntyre A (1984) After Virtue, 2nd edn. University of Notre Dame Press, Notre Dame

Martins H (2020) Ministro da Educação defende que pais devem causar dor a filhos e que 'homem aponta o caminho' da família, Estado de Minas, 10 July 2020. https://www.em.com.br/app/noticia/politica/ 2020/07/10/interna_politica,1165937/ministro-da-educacao-pais-devem-causar-dor-filhos-homemcaminho.shtml. Access 10 August 2020 
Mendonça RF, Caetano RD (2020) Populism as Parody: The Visual Self-Presentation of Bolsonaro on Instagram. The International Journal of Press/politics 26:1-26. https://doi.org/10.1177/1940161220 970118

Meyer EPN (2021) Constitutional Erosion in Brazil: Progresses and Failures of a Constitutional Project. Hart Publishing, Oxford

Meyer EPNeder, Bustamante T (2020) Authoritarianism Without Emergency Powers: Brazil Under COVID-19, VerfBlog, 04 Aug 2020, https://verfassungsblog.de/authoritarianism-without-emerg ency-powers-brazil-under-covid-19/, https://doi.org/10.17176/20200408-153025-0

Meyer EPN, Bustamante T (2021) COVID-19 in Brazil: A Sick Constitutional Democracy, VerfBlog, 22 Feb, 2021, https://verfassungsblog.de/covid-19-in-brazil-a-sick-constitutional-democracy/. Access 10 August 2021

Müller JW (2016) What is Populism? University of Pennsylvania Press, Philadelphia

Nogrady B (2020) What the data say about asymptomatic COVID infections. Nature 587:534-535. https://doi.org/10.1038/d41586-020-03141-3

Oliva G (2021) André Mendonça diz que cristãos estão dispostos a morrer pela liberdade. Poder 360, 07 April 2021, https://www.poder360.com.br/coronavirus/andre-mendonca-diz-que-cristaos-estaodispostos-a-morrer-pela-liberdade/. Access 10 August 2021

Paschoal CS (2020) O Novo Tom Axiológico da Expressão ‘Cidadão de Bem’: Refrações semânticas e Indícios de Estratificação da Sociedade Brasileira. Memento: Revista eletrônica de letras Universidade Vale do Rio Verde 11: 1-22. http://periodicos.unincor.br/index.php/memento/article/view/ 6130. Accessed 10 Aug 2021

Phillips D (2019) Hundreds of new pesticides approved in Brazil under Bolsonaro. The Guardian, 12 June 2019, https://www.theguardian.com/environment/2019/jun/12/hundreds-new-pesticides-appro ved-brazil-under-bolsonaro. Access 10 August 2021

Philips T (2020) Bolsonaro says he 'wouldn't feel anything' if infected with Covid-19 and attacks state lockdowns. The Guardian, 25 March 2020, https://www.theguardian.com/world/2020/mar/25/bolso naro-brazil-wouldnt-feel-anything-covid-19-attack-state-lockdowns. Access 10 August 2021

Poder 360 (2020) Bolsonaro chama governadores de 'projetos de ditadores' por medidas na pandemia, 05 Sept 2020, https://www.poder360.com.br/governo/bolsonaro-chama-governadores-de-projetos-deditadores-por-medidas-na-pandemia/. Access 10 August 2021

Postema GJ (2019) Utility, Publicity, and Law: Essays on Bentham's Moral and Legal Philosophy. Oxford University Press

Py F (2020) Bolsonaro's Brazilian Christofascism during the Easter period plagued by Covid 19. International Journal of Latin American Religions 4:318-334. https://doi.org/10.1007/s41603-020-00120-4

Rangel, LH (2020) Report: Violence Against Indigenous Peoples in Brazi - 2019 Data (Indigenist Missionary Council and National Conference of Brazilian Bishops 2020). Available at www.cimi.org.br. Accessed 10 August 2021

Rauscher F (2017) Kant's Social and Political Philosophy. In: Zalta EN (ed), The Stanford Encyclopedia of Philosophy (Spring 2017 Edition). https://plato.stanford.edu/archives/spr2017/entries/kant-socialpolitical. Accessed 10 August 2021

Rawls J (2001) Justice as Fairness: A Restatement. Harvard University Press, Cambridge, Mass

Raz J (1999) Engaging Reason. Oxford University Press, Oxford

Raz J (2001) Value. Cambridge University Press, Cambridge, Respect and Attachment

Raz J (2019) The Law's Own Virtue. Oxf J Leg Stud 39:1-15. https://doi.org/10.1093/ojls/gqy041

Sajo A, Holmes S, Uitz R (2021) Routledge Handbook on Illiberalism. Routledge, New York (forthcoming)

Santos R (2012) 'Cidadãos de bem’ com armas: Representações sexuadas de violência armada, (in)segurança e legítima defesa no Brasil. Revista Crítica De Ciências Sociais 96:133-164. https://doi.org/ $10.4000 /$ rccs. 4851

Salles JM (2020) A morte e a morte: Jair Bolsonaro entre o gozo e o tédio, Piauí 166, Julho 2020. https:// piaui.folha.uol.com.br/materia/a-morte-no-governo-bolsonaro/. Accessed 10 August 2021

Smith AE (2020) Covid vs. Democracy: Brazil's Populist Playbook. J Democr 31:76-90. https://doi.org/ 10.1353/jod.2020.0057

Solano E (2018) Crise da Democracia e extremismos de direita. Friedrich Ebert Stiftung, Análise No 42/2018. https://library.fes.de/pdf-files/bueros/brasilien/14508.pdf. Accessed 10 August 2021

Stanovich KE, West RF (2000) Individual differences in reasoning: Implications for the rationality debate? Behavioral and Brain Sciences 23:645-665. https://doi.org/10.1017/S0140525X00003435 
Sunstein C (2020) Too much information: Understanding what you don't want to know. MIT Press, Cambridge, Mass

The Guardian 2018. Brazil's Jair Bolsonaro threatens purge of leftwing 'outlaws', 22 Oct, 2018. https:// www.theguardian.com/world/2018/oct/22/brazils-jair-bolsonaro-says-he-would-put-army-on-stree ts-to-fight . Accessed 10 August 2021

Taylor C (1985) Atomism. Philosophical Papers, Vol II: Political Philosophy. Cambridge University Press, Cambridge, pp 187-210

Taylor C (1989) Sources of the Self: The Making of the Modern Identity. Cambridge University Press, Cambridge

The Economist (2021). Brazil's army is trying to distance itself from Bolsonaro,10 April 2021, https:// www.economist.com/the-americas/2021/04/08/brazils-army-is-trying-to-distance-itself-from-jairbolsonaro. Accessed 10 August 2021

Thunström L et al (2016) Strategic Self-Ignorance Journal of Risk Uncertainty 52:117-136. https://doi. org/10.1007/s11166-016-9236-9

Tommaselli GCGarcia, (2020) Necropolítica, racismo e governo Bolsonaro. Caderno Prudentino De Geografia 42:179-199

Tuck R (2008) Free Riding. Harvard University Press, Cambridge, Mass

Ullmann-Margalit E (2017) On Not Wanting to Know. Normal Rationality: Decisions and Social Order. Oxford University Press, Oxford, pp 80-92

Ventura DFL (2021) A parliamentary commission of inquiry (CPI) will investigate Brazil's Response to Covid-19 and the President's liability for one of the worst death rates in the world. Lex-Atlas Covid19, 27 April, 2021. https://lexatlas-c19.org/a-parliamentary-commission-of-inquiry-cpi-will-inves tigate-brazils-response-to-covid-19-and-the-presidents-liability-for-one-of-the-worst-death-rates-inthe-world/. Accessed 10 August 2020

Ventura DFL, Martins J (2020) Between Science and Populism: the Brazilian Response to COVID-19 from the Perspective of the Legal Determinants of Global Health. Brazilian Journal of International Law 17:67-83. https://doi.org/10.5102/rdi.v17i2.6687

Walzer M (1994) Thick and Thin. University of Notre Dame Press, Notre Dame, ID

Publisher's Note Springer Nature remains neutral with regard to jurisdictional claims in published maps and institutional affiliations. 